\title{
Proposed Unification of Indigenous Games in Teaching Physical Education in Cagayan National High School, the Philippines
}

\author{
Mark Lester P. Agustin ${ }^{1}$ \\ ${ }^{1}$ Teacher at Cagayan National High School, Tuguegarao City, Cagayan, Philippines
}

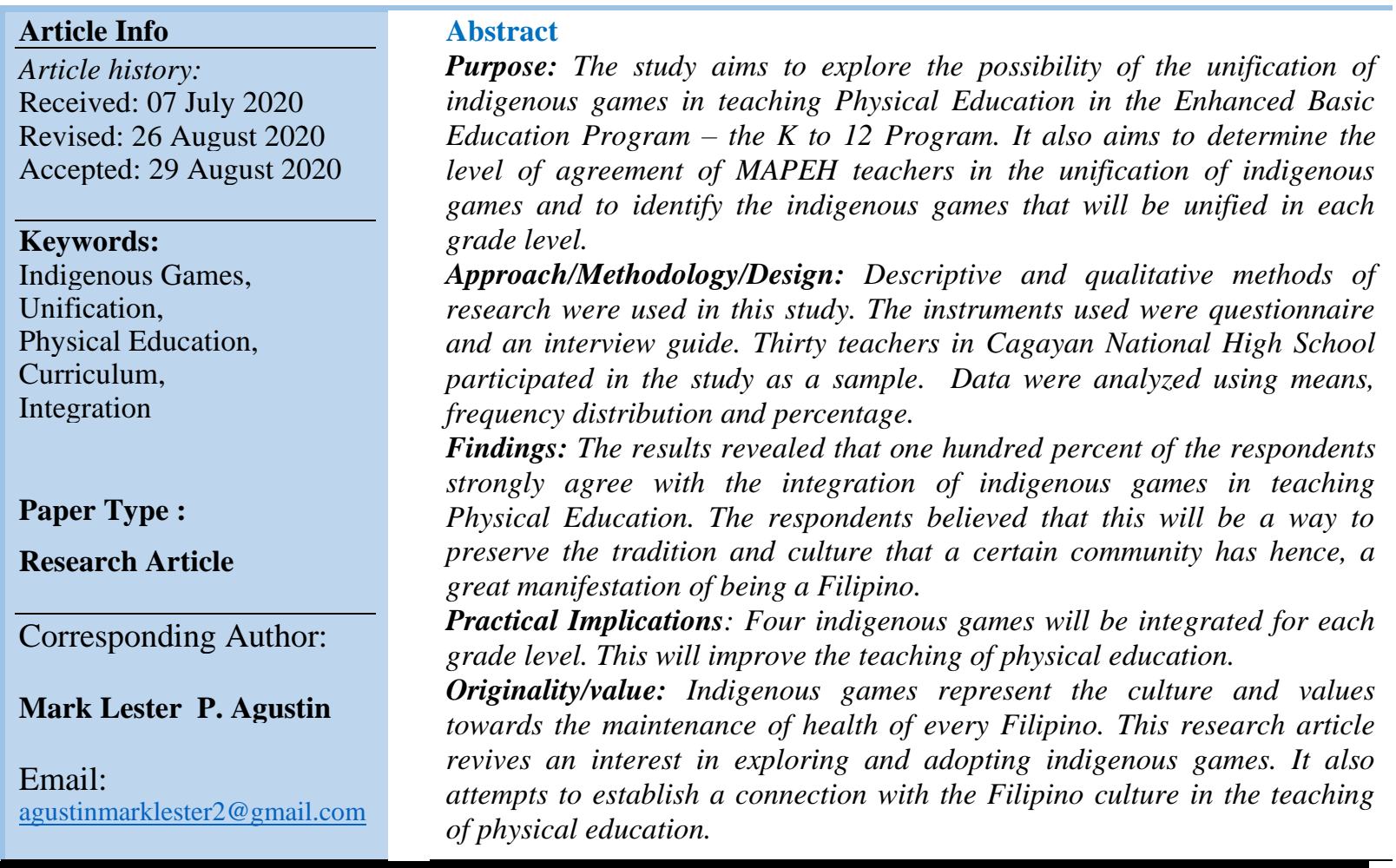

\section{Introduction}

Physical Education is one of the subjects in high school which balances the learning that the students could get from their subjects namely English, Science, and Mathematics and from their other subjects like the Technical - Vocational Education/Technology and Livelihood Education, "AralingPanlipunan", Filipino and the like. It is the subject that hones not only the cognitive aspect of the students but also the psychomotor and affective aspects through the different physical activities that a student can perform. Hence, it plays a vital role in the development of one's holistic personality. It is also through Physical Education that our values, beliefs and traditions especially in a certain locality could be passed from one generation to another. Studying Physical Education will equip today's young generation with the knowledge on the quality of human existence and our ancestral influence. This is one way of preserving them considering with the vast changes in our civilization due to the influence of the other countries and the existence of technology (Carag, 2020). 
The Department of Education is indeed very serious in its vision on "Quality Education". The implementation of the different programs in Physical Education will really train students and equip them with the necessary knowledge, skills, and attitudes that will make them physically, mentally and emotionally fit towards a better individual. Quality education therefore exists when effective Physical Education takes place. As a significant part of the Basic Education Curriculum ( BEC ) with the K to 12 Basic Education program, the effort in upgrading MAPEH in the general school curriculum becomes imperative. Nowadays, we live in a vast changing world in which issues and conflicts arise, and the entrance of modern technologies give way to innovations towards the modernization in the field of Physical Education. Hence, this kind of scenario challenged the researcher to propose a unification of indigenous games in teaching Physical Education to restore the culture and identity as Filipinos in sports through these indigenous games that will be inculcated into the minds and hearts of the students.

Indigenous games are the games that grew naturally in a certain place or community. These games manifest how one place is different from other places through the use of the different indigenous materials such as bamboos as in Palo Sebo, coconut shells in Kadang -kadang and coconut husks in Sambunotthat are available in the locality. The fundamental purpose of this study is to discuss a proposed unification of the indigenous games in teaching Physical Education that would greatly enhance the knowledge and skills of the students. The different games showcase the Filipino culture and enable the students to recognize the value of these games in their lives as Filipinos.

\section{Methodology and Procedures}

Descriptive and qualitative methods of research were employed in analyzing the data of the study. The descriptive design described the demographic information of the respondents in terms of age, civil status, highest educational attainment, designation or position in the school where they are working and their teaching experience in terms of years. It also determined the level of agreement of the respondents on the integration of indigenous games in teaching Physical Education and the different indigenous games to be integrated into the K-12 Basic Education Program in teaching Physical Education. The qualitative design measured the respondents' agreement with regard to the integration of the indigenous games in teaching Physical Education.

The respondents of the study were the MAPEH teachers of Cagayan National High School. Purposive sampling was used in the study. Thirty MAPEH teachers were considered as respondents of the study. Data were gathered through a questionnaire and an interview guide as research instruments in the study. The questionnaire was composed of four parts. The first part manifested the demographic information of the respondents. The second part was a 10item statement on the level of opinion as to the respondents' agreement with the integration of indigenous games in teaching Physical Education. Four - point Likert scale was used with 4 points as "strongly agree", 3 points as "somewhat agree", and so on. Another part of the questionnaire was a checklist of indigenous games in which the respondents selected the 
indigenous games they want to be integrated in teaching Physical Education from Grade 7 to Grade 10. The last part of the questionnaire was an interview guide which was used to collect deeper information as to their overview and recommendations of the respondents in the integration of indigenous games in teaching Physical Education.

A letter of permission from the school principal for approval before administering the questionnaire was furnished. In like manner, the researcher also asked permission from the respondents through a letter for their participation in the said study and eventually proceeded to an in-depth interview with them.

Data were analyzed through the use of descriptive statistics. Mean, frequency count and percentage are used in the analysis of data on the demographic profile of the respondents, the list of indigenous games to be unified in teaching Physical Education and the questions on the interview guide. Below is the scale that will be used to determine the respondents' level of agreement as to the unification of indigenous games in teaching Physical Education.

\begin{tabular}{|c|c|c|}
\hline Scale & Range & Adjectival Equivalent \\
\hline 4 & $3.25-4.00$ & Strongly Agree \\
\hline 3 & $2.50-3.24$ & Somewhat Agree \\
\hline 2 & $1.75-2.49$ & Agree \\
\hline 1 & $1.00-1.74$ & Disagree \\
\hline
\end{tabular}

\section{Results and Discussion}

The data obtained from the respondents is analyzed in this section. The results are also discussed and presented in relation to the aims of the study. The responses to the semistructured questions of the interview are analyzed and discussed one by one.

This study presented the imperative findings that would significantly contribute to the scholastic endeavours of the students to be implemented by their teachers. Table 1 shows the level of agreement of the respondents in the unification of indigenous games in teaching Physical Education. As reflected on the table, the respondents' level of agreement from statements 2 to 10 is "Strongly Agree" with a mean of 3.25. This manifests that they really want to unify indigenous games in teaching Physical Education to their students. They believe that teaching indigenous games is an exciting one because they can feel they are Filipino. This feeling encourages them to inculcate the cultural values into the minds and hearts of their students, and it here the importance of indigenous games lie. Through these games, the respondents strongly agreed that the students could still recall the culture that they have in their own places. Hence, traditional games will still exist through integrating them into physical education and reviving an interest among students.

Furthermore, the respondents believe that teaching these indigenous games to the students would develop and increase unity, love, and camaraderie among students and teachers where they could extend it to their families. However, for statement number 1, it is described as "Somewhat Agree" with a mean of 2.75. The table also shows that the weighted mean as to the level of agreement of the respondents is 3.20 which is described as "Somewhat Agree". 
Table 1: Level of Agreement of Respondents in the Integration of Indigenous Games in Teaching Physical Education

\begin{tabular}{|c|c|c|}
\hline Statements & Mean & Descriptive Values \\
\hline $\begin{array}{l}\text { I love playing indigenous games like Palo Sebo, } \\
\text { Jumping Rope, LuksongTinik etc. }\end{array}$ & 2.75 & Somewhat Agree \\
\hline I want to teach indigenous games to my students. & 3.25 & Strongly Agree \\
\hline $\begin{array}{l}\text { I can see that my students will be exciting when I } \\
\text { will teach them the indigenous games. }\end{array}$ & 3.25 & Strongly Agree \\
\hline $\begin{array}{l}\text { I can feel my being a Filipino through the indigenous } \\
\text { games. }\end{array}$ & 3.25 & Strongly Agree \\
\hline $\begin{array}{l}\text { I want to inculcate into the minds and hearts of my } \\
\text { students the importance of these games. }\end{array}$ & 3.25 & Strongly Agree \\
\hline $\begin{array}{l}\text { I want that my students could still recall the culture } \\
\text { that they have in their own places through the games } \\
\text { that they are playing using the indigenous materials. }\end{array}$ & 3.25 & Strongly Agree \\
\hline $\begin{array}{l}\text { I want to integrate indigenous games in teaching } \\
\text { Physical Education to show that our traditional } \\
\text { games still exist. }\end{array}$ & 3.25 & Strongly Agree \\
\hline $\begin{array}{l}\text { I feel excited when indigenous games will be part of } \\
\text { the lessons of my students. }\end{array}$ & 3.25 & Strongly Agree \\
\hline $\begin{array}{l}\text { I believe that indigenous games should still be taught } \\
\text { among students to inform them the traditional or } \\
\text { Filipino games that we have. }\end{array}$ & 3.25 & Strongly Agree \\
\hline $\begin{array}{l}\text { I believe that these indigenous games could develop } \\
\text { the unity, love and camaraderie among students } \\
\text { which they can share it to their family. }\end{array}$ & 3.25 & Strongly Agree \\
\hline $\begin{array}{l}\text { Weighted Mean } \\
\end{array}$ & 3.20 & Somewhat Agree \\
\hline
\end{tabular}

The respondents were requested to select at least eight (8) indigenous games per grade level from the list of indigenous games with Fifty - One (51) choices. However, less than eight indigenous games are still acceptable. The respondents think that those games selected are best suited for each grade level. The indigenous games that were selected are presented in Table 2. As shown in the table, respondent 1 selected seven (7) indigenous games for Grade 7, five (5) for Grade 8, four (4) for Grade 9 and six (6) for Grade 10. Respondent 2 selected six (6) for Grade 7, eight (8) for Grade 8, seven (7) for Grade 9 and seven (7) for Grade 10 then for respondents 3 and 4, they selected eight (8) for Grade 7, for Grade 8, respondent 3 selected six (6) while seven (7) for respondent 4, for Grade 9, respondent 3 selected eight (8) while respondent 4 selected four (4) and for Grade 10, respondents 3 and 4 selected seven (7).

Table 2: The Indigenous Games Selected by the Respondents

\begin{tabular}{|c|c|c|c|c|}
\hline $\begin{array}{l}\text { Grade } \\
\text { Level }\end{array}$ & Respondent 1 & Respondent 2 & Respondent 3 & Respondent 4 \\
\hline Grade 7 & $\begin{array}{ll}\text { 1. } & \text { LuksongLubid } \\
\text { 2. } & \text { LuksongTinik } \\
\text { 3. } & \text { PaluanngPalayok } \\
\text { 4. } & \text { KarerangSako }\end{array}$ & $\begin{array}{ll}\text { 1. } & \text { LuksongLubid } \\
\text { 2. } & \text { LuksongTinikA } \\
\text { gawan Base } \\
\text { 3. }\end{array}$ & $\begin{array}{ll}\text { 1. } & \text { LuksongLubid } \\
\text { 2. } & \text { LuksongTinik } \\
\text { 3. } & \text { Bati Cobra } \\
\text { 4. } & \text { Culliot }\end{array}$ & $\begin{array}{ll}\text { 1. } & \text { BulongPari } \\
\text { 2. } & \text { LuksongTinik } \\
\text { 3. } & \text { Paluanng } \\
& \text { Palayok }\end{array}$ \\
\hline
\end{tabular}




\begin{tabular}{|c|c|c|c|c|}
\hline & $\begin{array}{ll}\text { 5. } & \text { Lawin at sisiw } \\
\text { 6. } & \text { Pusa at aso } \\
\text { 7. } & \text { TumbangPreso }\end{array}$ & $\begin{array}{ll} & \text { DudleBal } \\
\text { 4. } & \text { Patamasa Bola } \\
\text { 5. } & \text { Patintero } \\
\text { 6. } & \text { Sipa }\end{array}$ & $\begin{array}{ll}\text { 5. Dama } \\
\text { 6. Paluanng } \\
\text { Palayok } \\
\text { 7. } & \text { Holen } \\
\text { 8. } & \text { KarerangLata }\end{array}$ & $\begin{array}{ll}\text { 4. } & \text { KarerangSako } \\
\text { 5. } & \text { Lawin at sisiw } \\
\text { 6. } & \text { Pusa at aso } \\
\text { 7. } & \text { Sipa } \\
\text { 8. } & \text { Tumbang Preso }\end{array}$ \\
\hline Grade 8 & $\begin{array}{ll}\text { 1. } & \text { Patintero } \\
\text { 2. } & \text { KarerangLata } \\
\text { 3. } & \text { Sipa } \\
\text { 4. } & \text { Sungka } \\
\text { 5. } & \text { Tatsing }\end{array}$ & $\begin{array}{ll}\text { 1. } & \text { BulongPari } \\
\text { 2. } & \text { Pabitin } \\
\text { 3. } & \text { Palo Sebo } \\
\text { 4. } & \text { Piko } \\
\text { 5. } & \text { Hand clapping } \\
\text { games } \\
\text { 6. Hole } \\
\text { 7. } \\
\text { 8arerang Sako } \\
\text { 8umbang Preso }\end{array}$ & $\begin{array}{ll}\text { 1. } & \text { Catch A Duck } \\
\text { 2. } & \text { Pallot } \\
\text { 3. } & \text { Patamasa Bola } \\
\text { 4. } & \text { Patintero } \\
\text { 5. } & \text { Sungka } \\
\text { 6. } & \text { Tatsing }\end{array}$ & $\begin{array}{ll}\text { 1. } & \text { Catch a Duck } \\
\text { 2. } & \text { Agawan Base } \\
\text { 3. } & \text { Bati Cobra } \\
\text { 4. } & \text { Palo Sebo } \\
\text { 5. Patamasa Bola } \\
\text { 6. Patintero } \\
\text { 7. } \\
\text { KarerangLata }\end{array}$ \\
\hline Grade 9 & $\begin{array}{l}\text { 1. Palo Sebo } \\
\text { 2. Pull and capture } \\
\text { 3. Pallot } \\
\text { 4. Pinal-siit }\end{array}$ & $\begin{array}{ll}\text { 1. } & \text { BulongBraso } \\
\text { 2. } & \text { Pallot } \\
\text { 3. } & \text { PaluanngPalay } \\
\text { ok } \\
\text { 4. }\end{array}$ & $\begin{array}{ll}\text { 1. } & \text { BulongBraso } \\
\text { 2. } & \text { Palo Sebo } \\
\text { 3. } & \text { Pataypatayan } \\
\text { 4. } & \text { KarerangKalab } \\
& \text { aw } \\
\text { 5. } & \text { KarerangSako } \\
\text { 6. } & \text { Pusa at aso } \\
\text { 7. } & \text { Sipasamangis } \\
\text { 8. } & \text { TumbangPreso } \\
\end{array}$ & $\begin{array}{ll}\text { 1. } & \text { Piko } \\
\text { 2. } & \text { Pinalsiit } \\
\text { 3. } & \text { KadangKadan } \\
& \text { g } \\
\text { 4. } & \text { Sipasamangis }\end{array}$ \\
\hline Grade 10 & $\begin{array}{l}\text { 1. AgawanngBiik } \\
\text { 2. AgawangSulok } \\
\text { 3. Dama } \\
\text { 4. Juego de Anillo } \\
\text { 5. Hand clapping } \\
\text { games } \\
\text { 6. Sambunot }\end{array}$ & $\begin{array}{ll}\text { 1. } & \text { KapitangBakod } \\
\text { 2. } & \text { AgawangSulok } \\
\text { 3. } & \text { Catch a Duck } \\
\text { 4. } & \text { Horse race } \\
\text { 5. } & \text { KarerangKalab } \\
& \text { aw } \\
\text { 6. } & \text { Kulliot } \\
\text { 7. } & \text { Juego de Anillo }\end{array}$ & $\begin{array}{ll}\text { 1. } & \text { Kulliot } \\
\text { 2. } & \text { Prisoners base } \\
\text { 3. } & \text { Juego de Anillo } \\
\text { 4. } & \text { KadangKadang } \\
\text { 5. } & \text { Sipa } \\
\text { 6. } & \text { Dama } \\
\text { 7. } & \text { Hand Clapping } \\
& \text { games }\end{array}$ & $\begin{array}{ll}\text { 1. } & \text { KapitangBako } \\
& d \\
\text { 2. } & \text { BulongBraso } \\
\text { 3. } & \text { Dama } \\
\text { 4. } & \text { Prisoners base } \\
\text { 5. Horse race } \\
\text { 6. Agawangsulok } \\
\text { 7. } & \text { Sambunot }\end{array}$ \\
\hline
\end{tabular}

The indigenous games to be unified for each grade level are presented in Table 3. As manifested on the table, there are four (4) indigenous games that were selected with a highest percentage among the rest for each grade level as suggested by $50 \%$ of the respondents, the other $25 \%$ of them suggested to have 1 to 2 indigenous games for each grade level while the other $25 \%$ is 7 or more. Four (4) indigenous games were considered for each grade level in such a way that there are four grading periods in one school year. Hence, there will be one (1) indigenous game to be integrated per grading period. Furthermore, the availability of tools and equipment in the selection of the indigenous games were also considered. The table shows that the indigenous games to be unified for Grade 7 are LuksongTinik, LuksongLubid", "PaluanngPalayok and TumbangPreso with a percentage suggestion of 100\%, 75\%, 75\% and $50 \%$ respectively. For Grade 8, Patintero which comprises 75\%, KarerangLata, Sungka, Palo Sebo which comprises $50 \%$ of the respondents who suggested these games. For Grade 9, $75 \%$ of the respondents suggested Kadang - kadang and 50\% of them also suggested Pull and Capture, SipasaMangis and BulongBraso while for Grade 10, 75\% of the respondents suggested Juego de anillo and Dama and 50\% suggested AgawangSulok and Kulliot. 
According to Buenviaje et al. (2004); Perez et al. (2004) and Tolentino et al. (2008), the common skills that will be developed in playing the indigenous games KarerangLata, PaluanngPalayok, Sungka, TumbangPreso, LuksongTinik, SipasaManigis, BulongBraso and Palo Sebo are balance, coordination and strength. The skills on speed, agility, flexibility, strength and also balance will be developed in playing Pull and Capture, "AgawanngBiik", Patintero, Kadang - kadang, Prisoner Base and AgawanSulok. For LuksongLubid, the skills to be developed are tuning, body coordination and rhythm while coordination and good decision making for Dama. Aside from the skills, the values among students will also be enhanced in playing these indigenous games. The common values that will be enhanced in playing these indigenous are sportsmanship, teamwork, obedience, honesty camaraderie, cooperation, patience and self - discipline.

Table 3: The Indigenous Games to be unified for each Grade Level

\begin{tabular}{|c|c|c|c|}
\hline $\begin{array}{l}\text { Grade } \\
\text { Level }\end{array}$ & Indigenous Games To Be Integrated & Frequency & Percentage \\
\hline \multirow[t]{8}{*}{ Grade 7} & LuksongLubid & 3 & 75 \\
\hline & LuksongTinik & 4 & 100 \\
\hline & PaluanngPalayok & 3 & 75 \\
\hline & TumbangPreso & 2 & 50 \\
\hline & Lawin at sisiw & 2 & 50 \\
\hline & Pusa at aso & 2 & 50 \\
\hline & Sipa & 2 & 50 \\
\hline & KarerangSako & 2 & 50 \\
\hline \multirow[t]{8}{*}{ Grade 8} & Patintero & 3 & 75 \\
\hline & KarerangLata & 2 & 50 \\
\hline & Sungka & 2 & 50 \\
\hline & Tatsing & 2 & 50 \\
\hline & Palo Sebo & 2 & 50 \\
\hline & Patamang Bola & 2 & 50 \\
\hline & Catch a Duck & 2 & 50 \\
\hline & BulongPari & 2 & 50 \\
\hline \multirow[t]{8}{*}{ Grade 9} & Pull and Capture & 2 & 50 \\
\hline & Kadang-kadang & 3 & 75 \\
\hline & BulongBraso & 2 & 50 \\
\hline & SipasaMangis & 2 & 50 \\
\hline & Palo Sebo & 2 & 50 \\
\hline & PaluanngPalayok & 2 & 50 \\
\hline & Pallot & 2 & 50 \\
\hline & Pinal-siit & 2 & 50 \\
\hline \multirow[t]{6}{*}{ Grade 10} & Juego de Anillo & 3 & 75 \\
\hline & AgawangSulok & 2 & 50 \\
\hline & Dama & 3 & 75 \\
\hline & Kulliot & 2 & 50 \\
\hline & Prisoners Base & 2 & 50 \\
\hline & Hand Clapping games & 2 & 50 \\
\hline
\end{tabular}




\begin{tabular}{|c|c|c|c|}
\hline & KapitangBakod & 2 & 50 \\
\hline & Sambunot & 2 & 50 \\
\hline
\end{tabular}

Based on the interview conducted by the researcher, almost all of the respondents agreed on the integration of indigenous games in teaching Physical Education. As it is shown in the tables, a $100 \%$ of the respondents agree that the students will enjoy playing these indigenous games. According to the respondents, the indigenous games represent the culture and values towards the maintenance of health of every Filipino. In addition to being enjoyable, the indigenous games and their related activities will help students to explore and develop their skills. The games will remind the students of the importance of their cultural values. Promoting these games through integration in teaching Physical Education will exuberantly preserve the culture that they have. Hence, the cultural values will be inculcated into every one's mind and heart. Integrating these games into physical education does not require numerous equipments. These games provide an avenue to develop physical fitness and promote unity and camaraderie among students and teachers.

The respondents also suggested that since the unification of these indigenous games in teaching PE are also intended to enhance the capabilities of students towards value formation and skills development. Therefore, there should be enough time allotted in teaching these games. Provision of materials and facilities must be given priority by the school administrators. The results of the study indicate a complete acceptance of the notion of the unification of indigenous games in teaching Physical Education. The respondents believe that as Filipino it is very important for them to be aware of the traditional games that they have. Integrating them into physical education means preserving their historical significance and also reconnecting with the tradition and culture that we have. This will only happen through the integration of these games into the K-12 Curriculum in the field of MAPEH particularly in Physical Education.

Four (4) indigenous games will be unified for each grade level as suggested by $50 \%$ of the respondents. Since there are four (4) grading periods in one school year, there will be one (1) indigenous game to be integrated per grading period. The indigenous games to be unified for Grade 7 will be LuksongTinik, LuksongLubid, PaluanngPalayok and TumbangPreso. For Grade 8, Patintero, KarerangLata, Sungka and BulongBraso are suggested. For Grade 9, the respondents also suggested Kadang - kadang, Pull and Capture, BulongngMangis and Palo Sebo. For Grade 10, these games Juego de Anillo, Dama, AgawangSulok and Kulliot were considered. The respondents had a positive thought that all students would enjoy these indigenous games. Aside from benefit that they could get in playing these games as to their fitness and skills like strength, balance, speed, agility and coordination, their values on camaraderie, team work, obedience, honesty, patience and most of all self- discipline will also be developed.

\section{Conclusion and Suggestion}


Based on data analysis, it is concluded that MAPEH teachers strongly believe that the integration of indigenous games in teaching Physical Education in the K- 12 Basic Education Program will be an avenue for the students to inculcate into their minds and hearts the tradition and culture that they have though these traditional games. Furthermore, indigenous games help students develop not only their skills but also enhance their cultural values. The results of the study reveal a wide acceptance for the integration of indigenous games into the teaching of physical education. Based on the findings, it is recommended that the MAPEH teachers should give indigenous games as an intervening activity in teaching Physical Education. For future researchers, it is recommended to have a follow- up study on this topic exploring the common indigenous games that are played by different ethnic groups.

\section{Conflict of Interest}

The author of this research article declares no conflict of interest.

\section{Funding}

This research study was not funded by any institution. The author conducted the study on his own expenses.

\section{References}

Aquilino, Eduardo P.. (2005). Active MAPEH III Activity -Based and Integrative Work text in Music, Arts and Physical Education For Elementary Pupils, Magallanes Publishing House.

Buena, G. \&Briones, T.(2007). MAPEH I, Vicarish Publication and trading Inc.

Carag, E. (2020). Pedagogical Approaches used by Teachers in Teaching MAPEH in the

Division of Tuguegarao City, Philippines. International Journal of Psychosocial Rehabilitation. 24 (8).678-691. http://doi.10.37200/IJPR/V2418/PR280071

Perez, A.(2006). MAPEH I Activity-Based and Integrative Work text in Music,

Arts, Physical Education and Health for Secondary Students, Magallanes Publishing House.

Perez, V.(2004). MAPEH II, St. Bernadette Publishing House Corporation. .(2005). MAPEH I St. Bernadette Publications, Inc.

Reyes, C. A. D. (2010). From physical recreation to digitisation: A social history of children's games in the Philippines. In Negotiating childhoods (pp. 99-109). Brill.

Santiago, G.(2004). MAPEH I, St. Augustine Publications Inc.

Tolentino, V.(2008). Honing Your Skills Through MAPEH (First Year). JO-ES

Publishing House Inc.www. jo-espublishing.com.ph

Wi, C.2004).MAPEH II, Phoenix Publishing House Inc., 